\title{
A Review of Secchi's Contribution to Marine Optics and the Foundation of Secchi Disk Science
}

By Jaime Pitarch

FIGURE 1. Luksch's polished white painted Secchi disk, $45 \mathrm{~cm}$ in diameter,

was used onboard the vessel Pola.
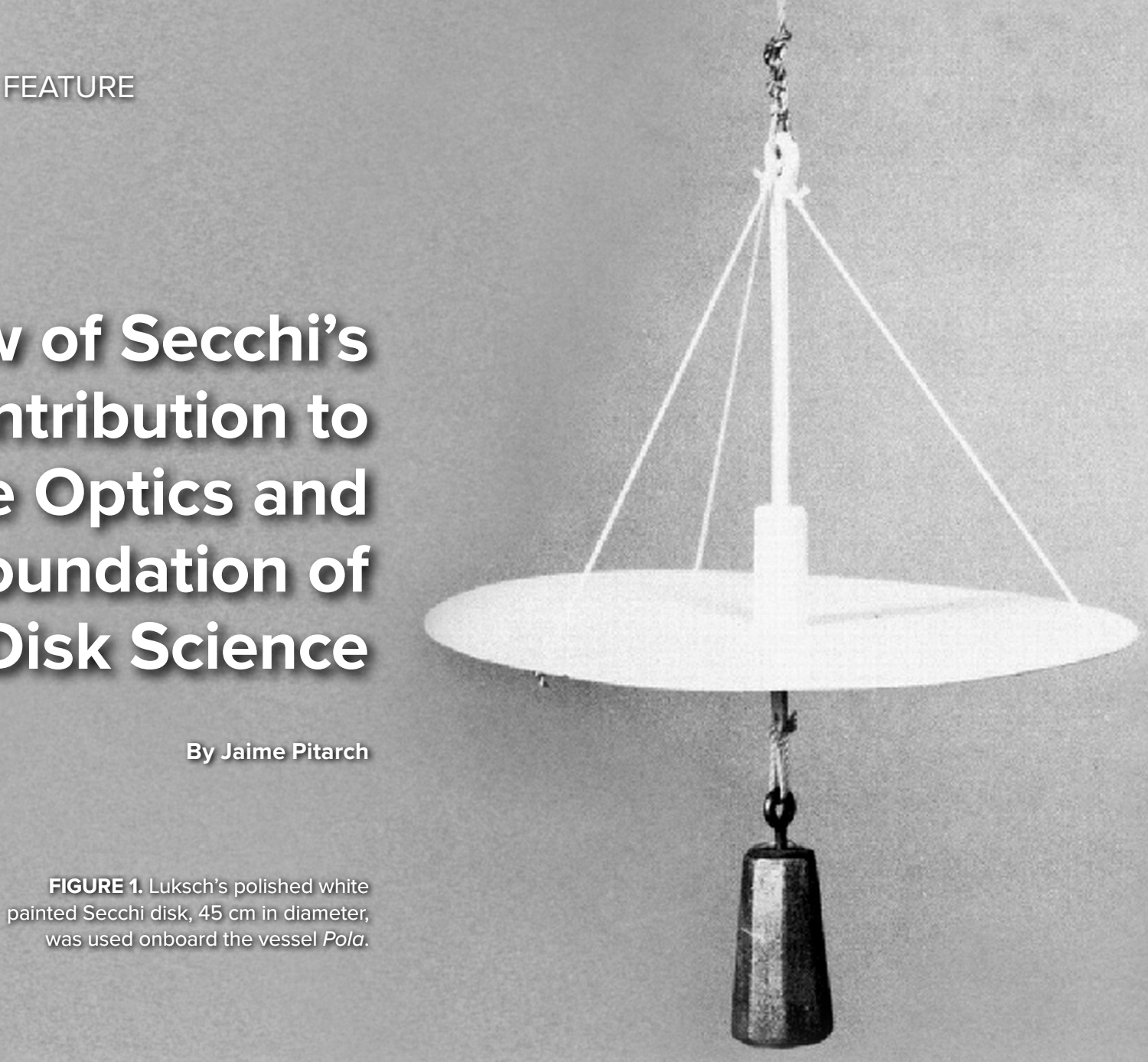

This manuscript is dedicated to the memory of Marcel Wernand (1952-2018), who I had the fortune to work with before I replaced him as head of the marine optics research group at the Royal NIOZ. He enthusiastically introduced me to the historical study of marine optics with his discussions of ancient instrumentation, expeditions, maps, methods, and anecdotes. Even after his passing, he continued to be an inspiration as I began to examine all the historic and scientific material he left.

ABSTRACT. Angelo Secchi was an astrophysicist and a pioneer in the use of spectroscopy in that field and also contributed to meteorology and geodesy. His only contribution to oceanography was on the physics of the "Secchi disk," a simple device that provides a measure of water transparency. While the Secchi disk was widely adopted after his death, the cruise report Secchi wrote in 1865 has unfortunately remained ignored, despite addressing many crucial questions in marine optics, such as how the angle of the sun, the disk's color and directional reflectance, the disk's diameter, the ship's shadow, and cloudiness influence the transparency measurements. This article aims to correct these oversights by calling attention to the scientific contributions of Angelo Secchi to optical oceanography. It shows how his training as an empirical physicist, his meticulousness, and his dedication enabled him to establish Secchi disk science.

\section{INTRODUCTION}

The Secchi disk (Figure 1) is a reflective white disk that is attached to a rope and lowered down the water column until it goes out of sight from above the surface. The depth at which it disappears is known as the Secchi disk depth $\left(\mathrm{z}_{\mathrm{SD}}\right)$, named after the astronomer Angelo Secchi, who described the method and provided insight on its physics in a cruise report (Secchi, 1865). Long before Secchi's contribution, measuring water transparency by lowering a bright object was already practiced in research as well as to ensure safe navigation, in particular, to assess water visibility and discern submarine cliffs, sandbanks, shoals of fish, currents, and proximity to the coast (Wernand, 2010). Somehow the technique ended up adopting Secchi's name-remarkable for a scientist whose single cruise report was his only contribution to oceanography and who had no particular reputation and political influence within the 
oceanographic community.

It is even more surprising that Secchi's cruise report has received almost no attention among limnologists and oceanographers. It is common that seminal articles on methods that become standard garner thousands of citations, but Secchi's name is only briefly mentioned in the few historical accounts that acknowledge his pioneering role (Wernand, 2010; Wernand and Gieskes, 2011). Citations to his report are systematically missing in articles that present Secchi disk data or discuss Secchi disk visibility theory. It seems that his report has largely been forgotten.

Here, I endeavor to delineate and understand Secchi's seminal work from a modern perspective. Considering his 1865 cruise report in the context of his full scientific career and the context of the time should provide a more complete understanding of his rationale and judgment. For this reason, a short biographical note is also included.

\section{SECCHI'S CRUISE ABOARD THE STEAM CORVETTE IMMACOLATA CONCEZIONE}

Cruise Description, Materials, Methods, and Data

Alessandro Cialdi (1807-1882), commander of the Papal Navy, was an engineer by training and a scientist. Influenced by the French physicist and astronomer François Arago (1786-1853), Cialdi wanted to study the correlation among transparency, waves, and currents. In April 1865, Cialdi invited Secchi to join

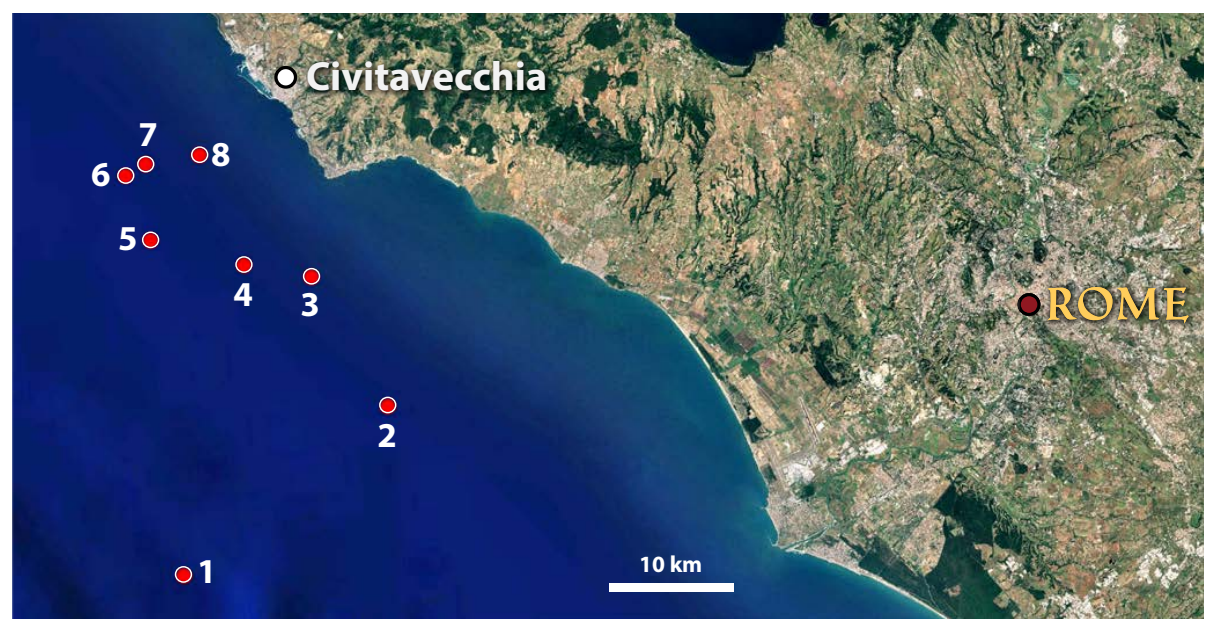

FIGURE 2. Map of stations of Secchi's cruise off Civitavecchia in 1865. Image source: Landsat, USGS

him in a measurement campaign aboard the pontifical steam corvette Immacolata Concezione, which was departing from the port of Civitavecchia (Figure 2). Secchi was responsible for the optical part of the research program, which included an analysis of the transparency and color of seawater relative to the sun's altitude, the weather, sea conditions, water depth, height from the water's surface, and the observer's eyesight. He wrote a report that was published in the journal Il Nuovo Cimento (Secchi, 1865), and this report was also included as a chapter in Cialdi's book (Cialdi, 1866). ${ }^{1}$

Based on Cialdi's instructions, ${ }^{2}$ Secchi prepared a disk of majolica ${ }^{3}$ with a diameter of $43 \mathrm{~cm}$ and a thickness of $2 \mathrm{~cm}$, fixed on top of an iron disk that was $60 \mathrm{~cm}$ in diameter. Another larger disk with a diameter of $237 \mathrm{~cm}$ was covered with white-painted sail fabric so that the influence of the disk's diameter on visibility in water could be determined. A spectrometer was used to study the composition of the light reflected by the disk at various depths. Anticipating the influence of the sun's elevation on the disk's disappearance depth, Cialdi took concurrent measurements of the sun's elevation (the angle between the horizon and the sun's center) with a sextant. ${ }^{4}$ Secchi noticed the high clarity of the sea and anticipated relatively high transparency ${ }^{5}$ due to the low biological productivity of the season. ${ }^{6}$

For each measurement, the disk was immersed from the sunny and from the shady sides of the vessel, "to see what influence the ship's shadow and the sun glint could have."7 Every immersion was made at least twice. People were placed at different positions such as on board, on the mast, or on a small boat. Observers were always perpendicular to the disk

\footnotetext{
An old English translation of this book seems to have been made decades ago by the US Department of the Navy, but it cannot be found online.

2 "[...] commander Cialdi ordered to make several disks of various diameters and colors, that had to be immersed in the sea until their sight were lost". [...] il sig. commend. Cialdi fece preparare varii dischi di diametro e di colore differenti che doveano immergersi nel mare fino a perdersi di veduta.

3 A porous, opaque ceramic product with hot-solidified varnish or enamel coating.

4 "[...] commander Cialdi measured the sun's height with a sextant [...]. The elevations we report here have already been corrected for the solar radius and for the horizon's depression, though not for refraction [air-sea interface]“ [...] il sig. Comm. Cialdi prendeva col sestante l'altezza del sole [...]. Le altezze che qui diamo sono già corrette del semidiametro del sole e della depressione dell'orizzonte, ma non della refrazione [interfaccia aria-acqua].

5 "From that day [three weeks before] on, there had been nothing more than a slight sea and a little wind, but this had ceased some days ago already: then the sea had to be very clean and had time to deposit every sediment. One must notice that over the coast in these places, there is not any considerable river that discharges turbid waters to the sea, and the Tiber itself is too far, and had not been laden for a long time". Da quel giorno in poi [tre settimane prima] non si erano avute che piccole marette, e un poco di vento di fuora, ma questo ancora era cessato da varii giorni: talché il mare dovea esser ben limpido e avea avuto tempo a depositare qualunque torbida. È da notare che sulla costa in questi luoghi non è vicino alcun fiume considerevole che scarichi in mare acque torbide, e il Tevere stesso è troppo lontano, e allora da gran tempo non era stato gonfio.

6 " [...] in these months, the sea is more transparent than in summer, maybe due to the lesser amount of tiny animals and other organisms that grow in the summer season." [...] in questi mesi il mare è più trasparente che nell'estate, forse per la minor quantità di animalucoli e altri organismi che vi si sviluppano nella stagione estiva. 
(nadir-looking), although occasionally an observer would be positioned away in the horizontal direction. The disk was observed as it sank by as many people as possible. When sight of it was lost, the depth was written down. The depth was determined to be the average of the estimates from all those who were observing the disk from the same place. Secchi noticed that there was normally very high agreement among all observers, even between him and the crew, who were more used to observing objects at sea, suggesting a somewhat universal perception between humans with healthy vision, regardless of experience. "Disagreement, if at all, was of a fraction of a meter."
Any differences were derived from causes external to the water quality. ${ }^{9}$

Secchi's data from this cruise were not georeferenced, which explains their absence in historical databases (NOAA, 2013). However, this lack of location accuracy can be remedied by using verbal descriptions of the position (e.g., "6 miles south of Cape Linaro") and bottom depth, which are available in Secchi's cruise report. The combined use of these verbal descriptions with a modern geomatic tool such as Google Earth permits retrieval of latitude and longitude. The station map in Figure 2 shows an offshore transect, away from any major river mouth, in deep, clear waters, despite the short dis- tance to land. Secchi's georeferenced data set is comprehensively compiled in a table in the online supplementary materials. In addition to the reported local time, an equivalent UTC time has been calculated from the position, sun elevation, and day.

\section{SECCHI'S FINDINGS}

The Secchi disk depth $\left(\mathrm{z}_{\mathrm{SD}}\right)$ depends on (1) water quality (its inherent optical properties), and (2) an array of factors such as the disk's characteristics (diameter, materials), sea state, cloud cover, shading, and illumination. While most researchers interested in marine and lake ecology have only paid attention to water quality, Secchi focused all

\footnotetext{
La discordanza, se talora vi fu, trovossi di una frazione di metro.

9 "[...] in the same experiment, the agreement among successive immersions is excellent, and if there is discrepancy, this mainly derives from other external circum-

stances such as the reflection on the water, the width of the shadow, the calm of the water, the direction of the rays, etc." [...] nel medessimo esperimento la concordia delle successive immersion è somma, e, se vi è diversità, questa deriva precipuamente dalle altre circostanze estrinseche differenti come sono il riflesso sull'acqua,

l'ampiezza dell'ombra, la quiete dell'acqua, la direzione de' raggi, ec.
}

\section{Box 1. Secchi's Life and Achievements}

Angelo Francesco Ignazio Baldassarre Secchi (1818-1878) was born on June 28,1818 , in the city of Reggio Emilia (Duchy of Modena and Reggio, presently in Italy). His first name is often mistakenly assumed to be "Pietro" by foreign readers, due to his signature as "P.A. Secchi." In fact, "P" stands for "Pater" (Father), which appears in his many publications in French as Père and might have been mistranslated back to Italian as "Pietro." As the last-born son of a modest family, Secchi joined the Church as the only means of pursuing studies. In Rome, the capital of the Papal States, he received an education in theology and physics at the Roman College, an institution for religious and academic training of Jesuits. Years later, after the death of the former director, astronomer Francesco de Vico, Secchi was appointed the director of the Roman College Observatory, where he would spend his entire career.

While at the Roman College Observatory, Secchi pioneered the use of spectroscopy in astronomy, applying this technique to classifying stars by spectral types. Secchi spent years observing double stars, which led to the publication in 1860 of a catalog of 1,321 double stars (Secchi, 1860). During these years, he made observations of clusters, nebulae, planets, and comets as well.

Solar physics was another major field of Secchi's research. He measured the sun's radiation and observed its prominences and spots. Secchi led a scientific expedition to Spain to observe the total solar eclipse of 1860 , capturing photographs of the solar corona and the prominences (Secchi, 1863). Analysis of all these photos, combined with measurements made with different instrumentation and under different atmospheric conditions during this and several other expeditions, confirmed the real nature of solar prominences.

Secchi studied meteorology and is regarded as a pioneer in the use of isobar maps for weather forecasting. Secchi conceived meteorol- ogy as a complex physical problem, in which a complete understanding could only be achieved after the systematic recording of a large array of variables. He is known for building the meteorograph, a precursor of an automated weather station (Secchi, 1870). The meteorograph was awarded the Grand Prix at the Universal Exhibition held in Paris in 1867.

Secchi was also an all-purpose geoscientist and civil engineer for the Papal States. His broad-ranging contributions included defining meridians and observing the sun's transit across them to determine the exact moment of noon; involvement in campaigns to acquire triangulations and geodetic measurements; organizing distribution systems for potable water; and studying atmospheric electricity, which led to installation of rods to protect Rome's main monuments from lightning. Secchi designed fire protection systems and made suggestions for the reconstruction of buildings that had been affected by earthquakes. He also studied Rome's climate and its influence on the flow of the Tiber River, carefully examining data on rainfall, wind, and temperature in the areas of the Tiber basin.

Secchi was a brilliant communicator. His documents are written in a rich and pedagogical style. He did not hesitate to give public lectures and disseminate science among the less educated social classes. Secchi greatly encouraged amateur astronomers and promoted astronomy education. He was held in high esteem internationally, witnessed by the numerous treatises published and translated into several languages, the cordial welcome he received during his travels abroad, and the many international prizes he was awarded. Secchi was a fellow of the most prestigious international academies and committees. His name can be found in their official publications as well as in international scientific journals of the time.

Despite his broad and relevant scientific productivity, historiogra- 
his attention on the array of factors that could affect depth readings. This section is organized similar to Secchi's (1865) cruise report. When needed, data from other authors are added for comparative analysis.

\section{The Disk's Influence on \\ Perceived Color}

Secchi reported that a white disk in water acquires a color that is different from that of the surrounding water, and this color varies as the disk sinks. ${ }^{10}$ This visual per- ception was confirmed by simultaneous observations with a spectrometer as the disk was lowered. The author recently studied this phenomenon using radiative transfer simulations (Pitarch, 2017). The explanations Secchi gave on this effect were deep, detailed, and enlightening, ${ }^{11}$ though they could only be phenomenological because 58 years needed to pass before Raman (1922) provided a physical explanation for the blue color of ocean water. Secchi made the distinction between shortwave radiation and longwave radiation and their different attenuation rates. Water strongly absorbs and scatters-attenuates-longwave radiation, while shortwave radiation is less attenuated as it travels through water. Therefore, a white disk, when held at a depth intermediate between the surface and $\mathrm{z}_{\mathrm{SD}}$, reflects incoming solar radiation whose spectral components have been attenuated to very different degrees when they return to the surface. For the blue waters of the Tyrrhenian Sea, red radiation (longer wavelength) is very

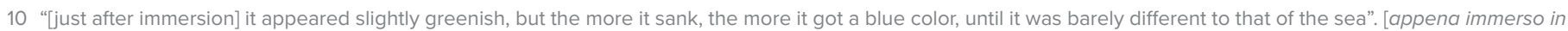
acqua] esso appariva leggermente verdino, ma più discendeva e più acquistava di colore azzurro, finchè appena era più slavato di quello del mare.

11 "The greenish color one first has derives from that fact that, at shallow depth, marine water still diffuses some yellow and red rays, as one can check with the spectrometer, but as depth increases, these two colors vanish a lot so green and the other highly refractive colors remain dominant. As depth increases further, even green becomes very poor, and we verified with the spectrometer that the rays that lay near the Fraunhofer line b [about 517 nm, green color] are particularly very absorbed, and only the most refractive colors remain. This explains the color of the water at depth, which is a mixed violet-blue." /l color verdino che si ha da principio deriva da cio che a piccola profondità l'acqua marina diffonde ancora un po' de raggi gialli e rossi, come si può assicurare collo spettrometro, ma crescendo la profondità queste due tinte si illanguidoscono assai e resta dominante il verde e gli altri colori più rifrangibili. Crescendo vieppiù la profondità, anche il verde diviene assai povero, e collo spettrometro ci siamo assicurati che restano specialmente molto assorbiti i raggi che stanno presso la riga b [sui $517 \mathrm{~nm}$, colore verde] di Frauenhofer [Fraunhofer], e rimangono quasi unicamente i colori più rifrangibili dello spettro. Ciò spiega il colore dell'acqua di mare a grande profondità, che è un azzurro misto di violaceo.

phy has been largely silent on Secchi and his scientific works, which is partially attributable to the complexity of his personality and the political implications of being a Catholic and a Jesuit. A scientific dispute with the British astronomer Lockyer, who was chief editor of the journal Nature, had a major effect on the circulation of Secchi's works. The most serious consequence was that no work by Secchi was translated into English. Among the English-speaking audience, his ideas circulated only thanks to quotations in American texts.

In the United States, Secchi's legacy was much appreciated. In 1935, the International Astronomical Union named a crater, a mountain chain, and a crevasse on the moon's surface after Secchi. In 1973, a crater on Mars was named for him, and in 1988, an asteroid. A NASA instrument that was launched in 2006 bears the acronym SECCHI (https://secchi.nrl.navy.mil). In Rome, only a couple of discrete busts honor his memory (Figure B-1).

This section has benefited from lleana Chinnici's biography of Secchi, Decoding the Stars (Chinnici, 2019). The book is a full account of Secchi's life and career, written reports, and correspondence. This biography provides the historic context of that time, which saw the shrinking and fall of the Papal States.

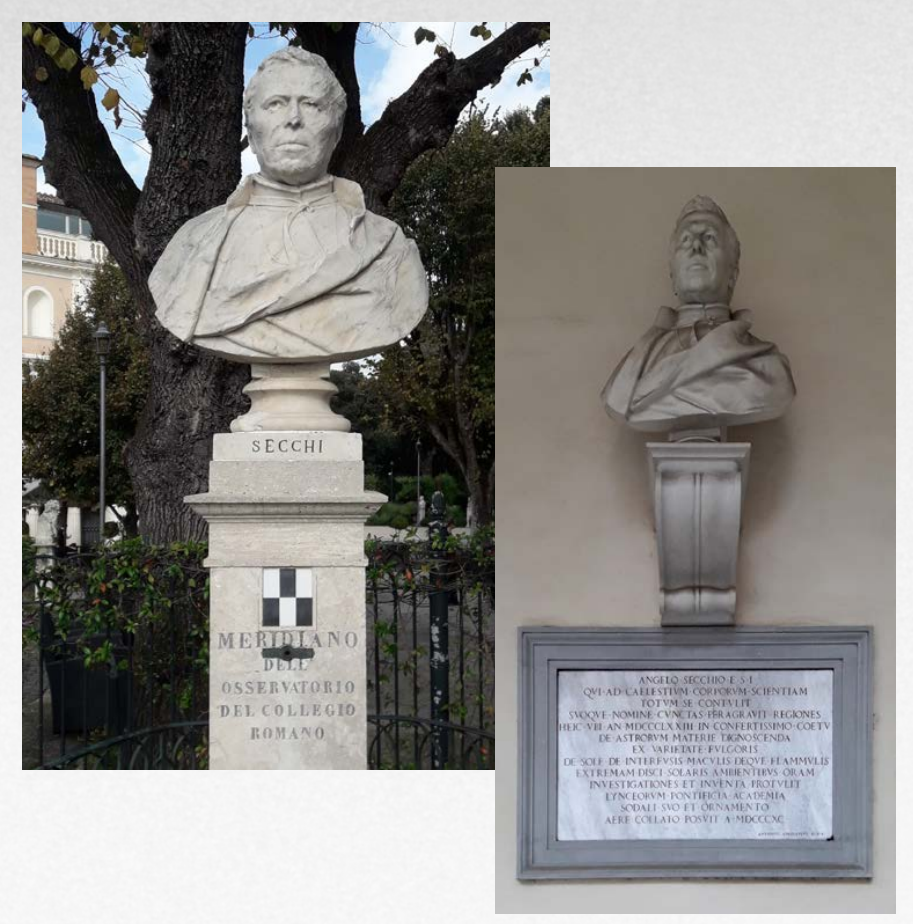

FIGURE B-1. Busts of Secchi in Rome. (left) This bust, placed in 1878 shortly after Secchi's death, is located on Pincio Hill in Villa Borghese, next to Casina Valadier, at the site of the first meridian to be determined in Rome $\left(12^{\circ} 27^{\prime} 8.4^{\prime \prime} \mathrm{E}\right)$. The Roman College Observatory identified the site in 1860 , 1,236 m away from the observatory, to adjust the observation of the meridian circle. (right) This bust was placed in 1891 in the courtyard of the Palazzo della Cancelleria Apostolica, where the headquarters of the Pontifical Academy of Nuovi Lincei were located. The memorial plaque reads, in Latin, "To Angelo Secchi of the Society of Jesus, who devoted himself entirely to the science of celestial bodies, and in its name, he traveled to all regions. Here, in the Pontifical Academy of the Lincei, in the year 1873, in a very crowded meeting, he presented researches and discoveries on the knowledge of the matter of the stars, based on the diversity of their brightness, on the sun, on the spots placed here and there [on its surface], on the prominences that are on the extreme circumference of the solar disk. To honor this fellow, a collection was taken up to place this in the year 1890 . Antonio Angelini of the Society of Jesus." Photo credit: Jaime Pitarch, November 2019 
strongly attenuated, whereas blue radiation (shorter wavelength) is only minimally attenuated, and green radiation is attenuated at intermediate levels. Overall, the color perceived from above is somewhat greenish.

This red shift happens at other regions of the visible spectrum as well. In 1917, the Soviet geographer Nikolay I. Vorob'yov (1894-1967) surveyed lakes in the Trans-Volga part of the Kozmodemyansk district, Kazan province. Deploying a Secchi disk in the small, humic Lake Glubokoye, near Kazan, he reported "Water in the lake [...] is of yellowish color, [...] and on the background of a Secchi disk, submerged at $1 \mathrm{~m}$, it is seemed to be orange-red. Transparency is $1.5 \mathrm{~m}^{\text {"12 }}$ (Воробьёв, 1926). ${ }^{13}$

When visual estimates of water color using the Forel-Ule comparator scale became popular in the early decades of the twentieth century, practitioners recommended that, if a Secchi disk was available, water color needed to be estimated by looking at a submerged disk at a given depth, usually $\mathrm{z}_{\mathrm{SD}} / 2$ or $1 \mathrm{~m}$ (Graham, 1966; Wernand and van der Woerd, 2010). This recommendation probably arose from the need to increase the brightness of the spot, as the water reflectance is often low,

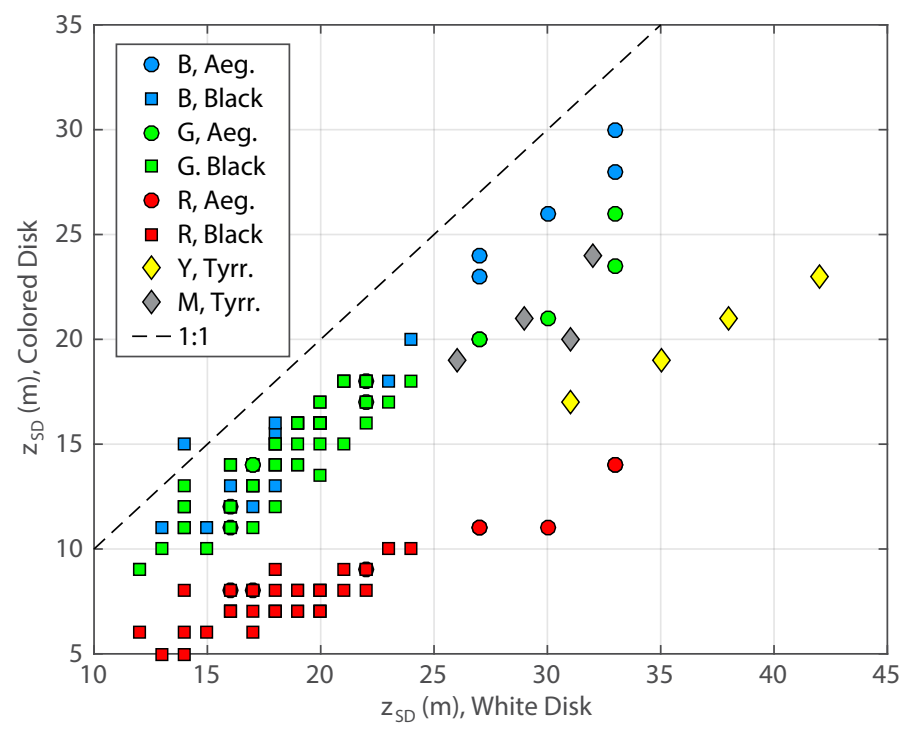

FIGURE 3. Comparison between Secchi disk depths $\left(z_{\mathrm{SD}}\right)$, measured nearly simultaneously at the same stations, using a white disk and colored disks of the same material and dimensions. The symbol color indicates the color of the disk on the vertical axis: B, G, R, Y, and $M$ are blue, green, red, yellow, and mud. The symbol shape indicates the sea in which the measurements were collected: Aegean, Black, or Tyrrhenian. which makes color estimation difficult. However, as early evidence showed, the color of the water column above a Secchi disk is red-shifted with respect to its real color.

\section{On the Water's Transparent Window}

Secchi measured the light spectra reflected by the sinking disk. He realized that, at the limit of visibility, only a narrow spectral window remained; its color was the same as that of the surrounding water, so contrast was finally lost, making the disk disappear. ${ }^{14}$ This spectral window of light that can penetrate deep is the basis of Lee's Secchi disk visibility theory (Lee et al., 2015).

Secchi also discussed light availability at greater depths, below $\mathrm{z}_{\mathrm{SD}}$. He criticized the French scientist Pierre Bouguer and other photometrists ${ }^{15}$ for ignoring that light is absorbed ${ }^{16}$ more strongly in the upper layers ${ }^{17}$ than in the lower ones, not only because light is more energetic there but also because it is spectrally heterogeneous. Bouguer (1729), based on the light attenuation rate in a surface layer, estimated that light in seawater should vanish at $83 \mathrm{~m}$ depth. Secchi correctly argued that the attenuation rate decreases with depth so downwelling light penetrates even further, acquiring the color of the background light at those depths.

\section{Influence of the Disk's Characteristics on Visibility}

As a trained spectroscopist, Secchi understood that the disk's reflectivity, which varies depending on its physical properties, would affect its visibility. To isolate any effect of physical properties, a disk of the same material as the larger one (sail fabric painted white) was fabricated with a diameter equal to that of the small one. Using two small disks that had the same color but were made of different materials, Secchi compared the visibility at two stations. The disk made of majolica was visible $2 \mathrm{~m}$ and $3 \mathrm{~m}$ deeper compared to the one made of sail fabric, demonstrating that majolica reflects more light than sail fabric.

Later in the cruise, experiments were conducted using disks of the same material and diameter, but different colors: the $43 \mathrm{~cm}$ disk made of sail fabric, painted white, plus two more painted yellow and muddy brown. Figure 3 compares the simultaneous measurements of the three disks. Secchi's data (diamonds) suggest that transparency is severely modified if the disk color changes.

\footnotetext{
12 Вода в озере [...] окрашена в желтоватый цвет, [...] а на фоне диска Секки, опущенного на 1 метр, кажется оранжево-красной. Прозрачность 1.5 метра.

13 This is the oldest reference I could find where a Secchi disk is used to visually estimate the color of the water.

14 "[...] these very scoured [filtered] colors, made homogeneous [spectrally narrow], could penetrate in the sea at great depth [...]. The phenomenon of the Blue Grotto at Capri near Naples, and at another one at Circeo Cape, which shows the same phenomenon, are caused by this colored light reflected from the water." [...] questi colori cosi purgati [filtrati] e resi omogenei [spettralmente ristretti] possano penetrare nel mare a grande profondità [...]. A questa luce colorata riflessa dall'acqua è dovuto, come è noto, il fenomeno della grotta azzurra a Capri presso Napoli, e dell'altra al promontorio Circeo che presenta lo stesso fenomeno.

15 The reader may note that Secchi is criticizing the application of the Beer-Lambert-Bouguer law to bulk light intensity because light inherently attenuates differently at different regions of the spectrum and therefore the proposition of a spectrally integrated attenuation coefficient is ill-conceived.

16 Today we refer to this concept as the attenuation of direct and diffuse downwelling irradiance.

17 Even for an ideal exponential attenuation, the attenuation rate is higher for high values in a linear scale.
} 
Given the small size of Secchi's data set for this experiment, a much larger amount of data collected by Vladimir I. Haltrin in the Black and Aegean Seas (Haltrin, 1998) is included in Figure 3 for comparative analysis. The plot highlights that colored disks provide lower readings than white disks, due to the lower reflectivity of the former and likely also different contrast. For a given sea, measurements with a white and a colored disk show an almost perfect linear relationship. Secchi's results with a yellow disk align perfectly between Haltrin's red and the green disks. The "mud" color has a broad spectrum, with much lower reflectivity than the white disk, which seemed to have an effect on visibility similar to a green disk (here we assume the color of the Tyrrhenian and Aegean Seas are roughly equal).

Haltrin calculated three different regressions for data between the white disk and the blue, green, and red disks, pooling data from both seas. Correlations were good, but a detail was missed: the data clouds for the blue and green disks tend to overlap for the Black Sea but diverge for the Aegean Sea. This result is consistent with the conceptual model of visibility as given in a narrow spectral window determined by water type. Sighting of an object in water is determined by the contrast of light between the object and the surrounding environment. In the blue-green waters of the Black Sea, the blue and green disks seem to reflect light similarly. On the other hand, the blue water of the Aegean Sea attenuates green light much more than blue light. Finally, the red color is clearly outside the transparent window for both the Black and Aegean Seas and disappears not only much more rapidly than disks of other colors but also keeps a consistent relationship with respect to the white disk irrespective of the sea. A red disk at depth will look black, and it is likely that a black disk (experiment not performed) would provide similar visibility.

\section{Influence of Cloud Cover on Visibility}

There was some occasional cloud cover during Secchi's expedition. He was concerned about how changes in the intensity and color of incident light could affect the measurement of disk depth. Using the two different sized white disks, he compared experiments conducted on two consecutive days in waters regarded as optically equivalent, with sun elevations within $1^{\circ}$. Table 1 presents the averages of all measurements for the same conditions.

This comparison is interesting because it shows no difference due to cloud cover for the small disk, but a difference of $\sim 10 \%$ for the large disk. Secchi reasoned that, for the small disk, the clouds had little influence because the limiting factor of the disk's visibility was the image distortion caused by the wavy surface, whereas the large disk remained identifiable, but deformed, until it disappeared due to contrast loss. ${ }^{18}$ Days later, with a flatter sea surface, Secchi reported a difference of $2.8 \mathrm{~m}$ for the small disk between measurements taken when high cirrus clouds were present and when clouds were absent.

Today, the effect of cloud cover is explained as follows. When clouds block the sun, the diffuse to direct radiation ratio is higher, which decreases the average cosine of downward irradiance in the water (irradiance is the amount of light
TABLE 1. Averages of several Secchi disk depth measurements made in similar waters, differentiated by disk type and sky condition. Sun elevations were all within $1^{\circ}$.

\begin{tabular}{ccc}
$\mathbf{z}_{\text {SD }}(\mathbf{m})$ & SKY CONDITION & DISK TYPE \\
\hline 32.34 & Sunny & Small \\
\hline 32.20 & Cloud Covered & Small \\
\hline 41.40 & Sunny & Large \\
\hline 36.70 & Cloud Covered & Large \\
\hline
\end{tabular}

energy from the sun and sky received per square meter each second; units are $\mathrm{W} \mathrm{m}^{-2}$ ), leading to a longer path length and lower vertical visibility. The smaller amount of absolute radiation when there is cloud cover may have less effect, as the human eye is known to adapt well to light intensity.

\section{Influence of the Disk's Diameter on Visibility}

The observer must track a surface element belonging to the disk's projection at the surface, which becomes smaller as the disk sinks, and is distorted by the continuously changing wavy surface. In Secchi's words, "It was noticed that the small plate vanished more quickly than the other one, mainly due to the water agitation and the refraction, which distorted the image in a very strange fashion and transported it to everywhere, and such effect contributed to making it disappear quicker. The plate's shape appeared then divided in two, and like a roughly delimited small cloud. The large disk, on the other hand, while also losing the regular contours, was never divided, and remained always quite large, continuous and visible, though also diffused like a cloud, but it did not go out sight until its color had become such laden that matched that of the water."19

\footnotetext{
18 " [...] the correction [difference] for the disk of majolica [the small one] is tiny, but it could derive from what we pointed out previously, that its disappearance was not all affected by absorption, but the agitation and continuous movement contributed as well, and because of that movement, it vanished before light made all its effect." [...] la correzione [differenza] del piatto di maiolica [quello piccolo] è piccolissima, ma ciò potrebbe derivare da ciò che acennammo dianzi, che per esso la disparizione non era tutto effetto di assorbimento, ma vi contribuiva anche la sua agitazione e il moto continuo, e per esso moto svaniva prima che la luce avesse fatto tutto il suo effetto.

19 Fu notato che il piatto piccolo svaniva più presto dell'altro, principalmente per la ragione che l'agitazione e la refrazione ne sformavano l'imagine in modo stranissimo, e la trasportavano per tutti i versi, e quel traballamento dovea contribuire a fare che si perdesse più presto. La figura del piatto talora appariva divisa in due, e come una nuvoletta mal terminata. II disco grande invece benchè anchor esso perdesse i suoi contorni regolari, non arrivava però mai a dividersi, e restava sempre abbastanza grande, continuo e visibile, benché sfumato ancor esso come una nube, ma non perdeasi di vista altro che quando la sua tinta era divenuta sì carica che eguagliava quella dell'acqua.
} 
Secchi was interpreting the disk's disappearance as an interplay of limiting factors. He attributed the disappearance of the small disk to the shape disintegration and disappearance of the large one to loss of color contrast. ${ }^{20}$ Therefore, he deduced that the increase in visibility that resulted from increasing the disk diameter had to be asymptotic. ${ }^{21}$ This effect is modulated by the visibility along the water column. If turbidity is high enough such that the small disk is angularly big when it disappears, the disk's diameter will have no

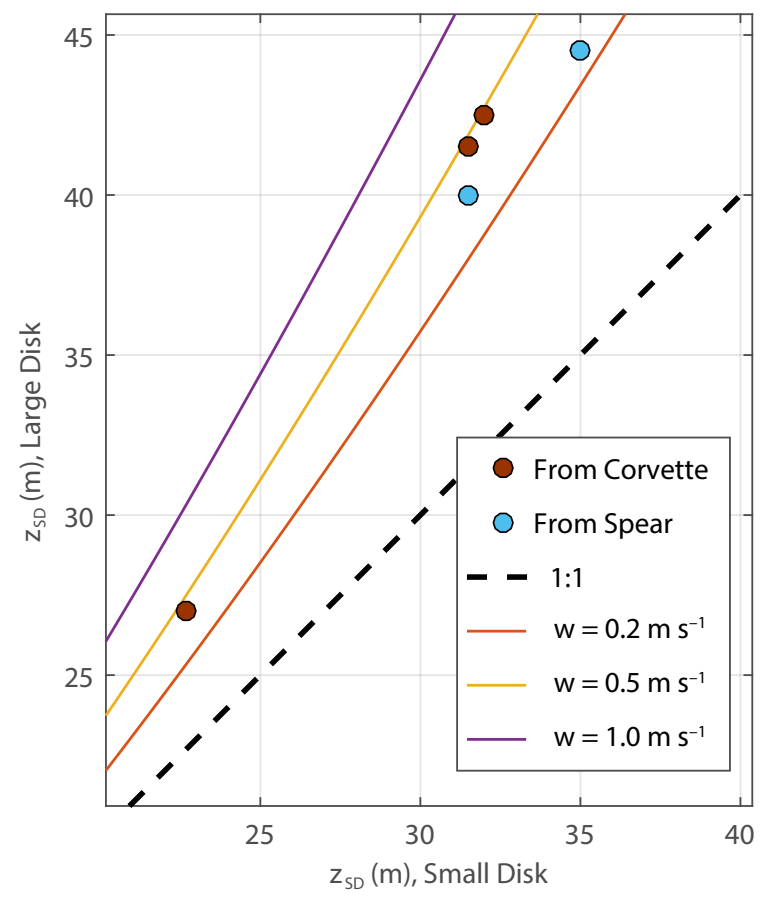

effect, whereas for greater depths, the diameter will become relevant. ${ }^{22}$

To separate the effect of the disk's diameter from that of the disk's fabric, Secchi's result in the previous section can be used, in which the disk made of majolica was visible $2 \mathrm{~m}$ and $3 \mathrm{~m}$ (mean $2.5 \mathrm{~m}$ ) deeper than the disk wrapped in sail cloth that had the same diameter and same white color. Therefore, comparison in Figure 4 includes this rough compensation, so that both disks can be assumed to be made of the same material. Only measurements made on the shady rather than the sunny side of the vessel were considered, as this choice has an effect as well.

Secchi's results can be evaluated against contrast reduction formulas used to account for wind stress (Preisendorfer, 1986). ${ }^{23,24}$ Given the different subtended angles of the small and the large disks, and assuming a coupling constant ${ }^{25} \Gamma=8$, the relationship between the visibilities of the large and the small disks can be calculated for different wind speeds (Figure 4). Indeed, the differences in visibility due to different disk sizes seem to be well explained even when assuming low wind speeds. For the diameters of $43 \mathrm{~cm}$ and $237 \mathrm{~cm}$, the differences in visibility can be $\sim 5 \mathrm{~m}(\sim 20 \%)$ for very low wind speeds in clear open waters. On the other hand, the impact of such size differences on visibility in turbid waters is minimal. The model predicts differences due to disk diameter of only a few centimeters for visibilities around $5 \mathrm{~m}$ and the same wind speeds.

\section{Influence of a Shadowed Sea \\ Surface on Visibility}

"It is known to sailors that, to see well at sea, one must look from the shaded side, or at least, from where one does not have the sun's reflection." ${ }^{26}$ Following Arago's recommendation, Secchi looked through polarized filters, though he reported unsatisfactory results when the ocean's

20 "Tranquility favors visibility very much because it conserves the stability of the shapes of the objects and keeps them less moved. The small plate becomes irregular due to refraction and becomes like a star, and below 25 meters one cannot figure out what shape it has. [...] The surface of the big plate, on the other hand, even becoming irregular, it is so vast that it never breaks apart. It becomes badly defined and diffused by a sort of whitish halo which forms around it and remains diffuse as a small cloud, but ceases from being visible only because its color loads so much that it becomes indistinguishable from that of the surrounding water." La tranquillità favorisce assai la visibilità, perchè conserva la stabilità della forma degli oggetti e li tiene meno agitati. II piatto piccolo diviene come una stella, e sotto 25 metri non si capisce più di che figura sia. [...] L'area però del piatto grande per quanto diventi irregolare essa è sì vasta che non si spezza mai. Essa diviene mal terminata e diffusa per una specie di aureola biancastra che gli si forma attorno, e rimane sfumata come una nuvoletta, ma cessa di esser visibile solo perché il suo colore si carica tanto che non si distingue più da quello dell'acqua circostante.

21 "It is therefore concluded that the size of the [disk's] surface, once reached a certain [upper] limit, does not have a significant influence on the visibility". Da questo risulta che la grandezza della superficie [del disco] arrivata a un certo limite [superiore] non ha sensibile influenza sulla visibilità.

22 The subtended angle between our eyes and the extremes of the disk depends on the distance from the disk to our eyes. If the disk is big, one sees it disappear in the water because it loses color contrast with respect to the surrounding water. If it is a small disk, the primary reason for the disappearance might be its fragmentation and distortion due to waves.

23 This NOAA report is less known than his Limnology and Oceanography paper, but it is much more interesting to read as it is free from the conservative bias of editorial and anonymous review. It still contains all the physics of the Secchi disk as well as free discussions about science, opinions, irony, personal accounts, and it is well written.

24 Fully recognizing that Lee's Secchi disk theory today has wider acceptance than Preisendorfer's, unfortunately the former does not provide means to consider variability due to factors like the disk's diameter or the wind speed, while the latter does. Therefore, for this comparative experiment, Preisendorfer's theory is used, notwithstanding references to Lee's theory in the rest of the paper. For example, Preisendorfer's theory does not explain variation with the sun elevation while Lee's theory naturally accounts for this effect.

$25 \Gamma$ is the coefficient that inversely relates $z_{S D}$ to the water's optical properties in Preisendorfer's model.

26 È noto ai marinai che per veder bene in mare bisogna guardare dal lato dell' ombra, o almeno dove non sia riflesso di sole. 


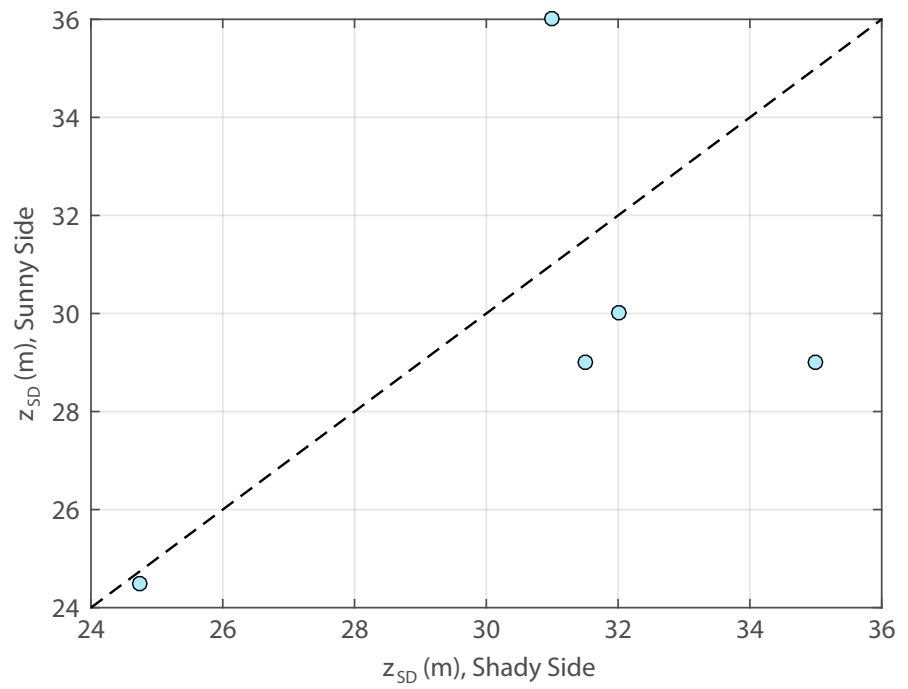

FIGURE 5. Comparison between the Secchi disk depth $\left(z_{S D}\right)$ estimated from the shady and from the sunny sides of the ship. All measurements were made by Secchi using a $43 \mathrm{~cm}$ majolica disk. Only measurements under clear or slightly covered skies were selected.

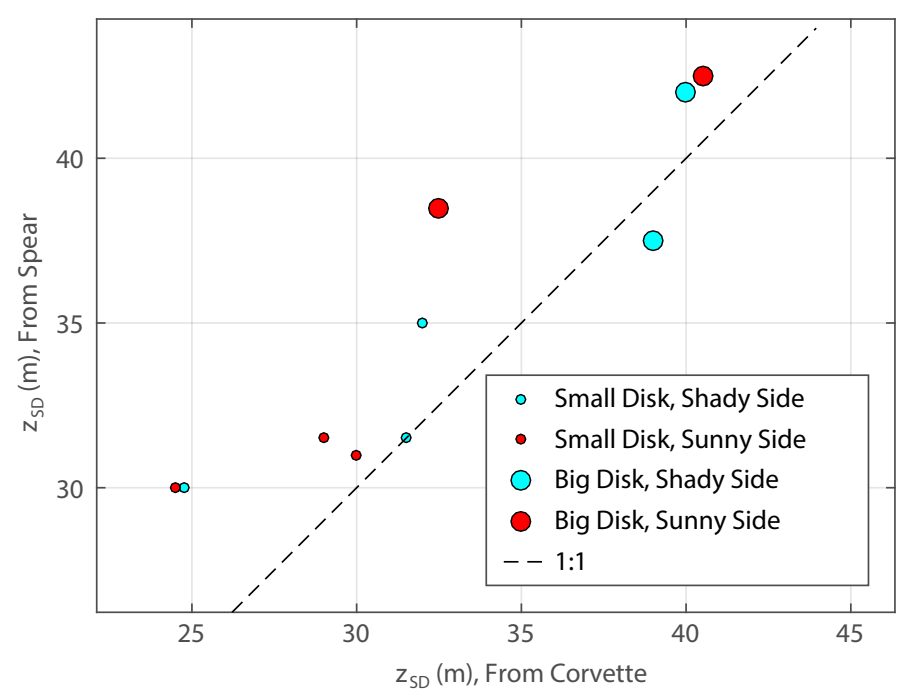

FIGURE 6. Comparison between the Secchi disk depth $\left(z_{S D}\right)$ estimated from the corvette and from a small spear boat, using the small and large disks deployed from the shady and from the sunny sides. surface was wavy ${ }^{27}$ and suggested that a better approach would be to project a shadow over the observation spot instead. Nevertheless, he noticed that when sun glint is avoided, the observed difference in depth between disks lowered from the shady or sunny side must be small, due to the limited reach of the ship's shadow vertically compared to $\mathrm{z}_{\mathrm{SD}}{ }^{28}$ Here, the eye's ability to adjust according to the incident light also works as a compensating factor. Preisendorfer (1986) also argued that by looking at the water from right above the surface on top of the disk, the observers would be blocking the sun glint at the disk's projection over the surface with their own shadows, improving the contrast.

Figure 5 compares Secchi's measurements taken from the shady and sunny sides of the ship, using the same disk and keeping all other conditions equal.
Results mostly confirm the beneficial effect of shade in removing sun glint and increasing visibility, in particular, at the station having the lowest transparency (where Secchi reported that the measurement on the sunny side was made with a very strong sun glint). Other interesting details also emerge from the data: the dot containing one pair of nearly equal values comes from measurements under a "slightly foggy sun,"29 where glint may have been naturally diffused. Regarding the anomalous dot (where the measurement from the sunny side is higher than from the shady side), Secchi concluded it resulted from the shade reaching the surface of the disk when the disk was lowered from the shady side, thus reducing the projected light on its surface. ${ }^{30}$

Secchi mentions the further benefits of using a shade-blocking tube or using the ship's structure to provide shade while making measurements. Years later, some practitioners adopted this idea, adding a glass at the lower end of the tube to also cancel the surface waves. Such a device was ultimately considered cumbersome and was discarded.

\section{Influence of the Observer's Altitude} Above the Surface on Visibility

Secchi suspected the observer's altitude over the disk ${ }^{31}$ would influence measurements. Experiments were conducted where $z_{S D}$ would be measured from a ship whose deck was about $4 \mathrm{~m}$ above sea level and also from a small boat at sea level. Direct comparison (Figure 6) showed that increasing the distance of the observer from the water surface reduces the disk's visibility because it reduces the subtended angle of the disk as seen from above.

27 "However, the advantage of this instrument [the polarizer] is null, because it does not remove it [the sun glint] all, due to the continuous fluctuations of the water that tilts the water surface to incidences which are not those of complete polarization." Tuttavia in pratica il vantagio di questo stromento è nullo, perchè esso non la toglie [la riflessione] mai tutta, atteso il continuo fluttuare dell'acqua che inclina la superficie ad incidenze che non sono quelle della polarizzazione completa.

28 [...] the vessel, having a draft of no more than four meters, the sun ray passed under it, and lit the disk even when it was at the shady side of the ship. [...] il bastimento, non pescando più di 4 metri, il raggio solare passava sotto di esso e andava ad illuminare il disco anche quando stava dal lato dell'ombra della nave.

29 Sole leggermente nebbioso.

30 "[in one experiment] one finds notable difference between those made at the sunny side and those others at the shady side because it seems that the disks were in the shady cone of the vessel." [all'incontro di un esperimento] si trova notabile differenza tra quelle fatte dal lato del sole e quelle altre dal lato dell'ombra, perché pare che i dischi sotto acqua stessero nel cono ombroso della nave.

31 But the sign of the variation with the observer's position was not clear to him a priori: "[...] a sailor was sent to the crow's nest to see if he could see better than us, but there was not any better result. Worse, actually". [...] fu mandato in alto sulla coffa un marinaio per sapere se vedeva meglio di noi, ma non ebbe nessun miglior frutto, anzi meno. 


\section{Influence of Sun Elevation}

\section{on Visibility}

To test the influence of sun elevation on disk visibility, Secchi selected measurements he believed were made in the same water type, which he gathered in a table, similar to Table 2. Based on the results, he wrote the following text in italics to bring attention to it: "So that the depth increases with the sun elevation." 32 This effect was "very evident" 33 to him, and he mentioned three causes of it.

First, it is possible that the difference in energy of the solar rays with the changing elevation of the sun affects visibility of the disk. Secchi guessed that the effect might be proportional to the irradiance reaching Earth's surface. At the time, there seemed to be some debate in the atmospheric physics community on the amount of radiation transmitted through the atmosphere, so Secchi preferred to leave the matter for further research.

Second, Secchi wondered how the angular reflectivity of the disk affected visibility. Specifically, he was concerned that if the disk did not reflect light equally in all directions, the results would be difficult to interpret in terms of the relative positions

TABLE 2. Measurements selected by Secchi to illustrate the influence of sun elevation on disk visibility. Measurements were made from the shady side of the ship.

\begin{tabular}{ccc}
$\begin{array}{c}\text { SUN } \\
\text { ELEVATION }\end{array}\left(^{\circ}\right)$ & $\mathbf{z}_{\text {SD }}(\mathbf{m})$ & DISK TYPE \\
\hline $30^{\circ} 4^{\prime}$ & 22.7 & Small \\
\hline $41^{\circ} 53^{\prime}$ & 27.3 & Small \\
\hline $59^{\circ} 39^{\prime}$ & 32.2 & Small \\
\hline $25^{\circ} 43^{\prime}$ & 24.5 & Large \\
\hline $45^{\circ} 25^{\prime}$ & 33.9 & Large \\
\hline $59^{\circ} 22^{\prime}$ & 36.7 & Large \\
\hline
\end{tabular}

of the sun, the disk, and the observer.

Third, Secchi considered the influence of sun elevation in changing the light propagation length in the water. A lot of space in his cruise report was devoted to this idea. "This path is not expressed by the simple vertical depth of the disk twice but must be determined in every case from the angles of the refracted incident ray, and the one reflected by the disk that reaches the eye." 34 The next note unfortunately has passed unnoticed through time: Secchi measured $\mathrm{z}_{\mathrm{SD}}=41.4 \mathrm{~m}$ when the sun's elevation was high at $60^{\circ} 13^{\prime}$. For such conditions, the oblique incident sun rays travel $44.56 \mathrm{~m}$ in water from the surface to the disk, leading to a total distance traveled by sunlight from the surface to the disk and back to the surface of $41.4 \mathrm{~m}+44.56 \mathrm{~m}=$ $85.96 \mathrm{~m}$. Secchi made the following quick calculation: assuming an equal amount of light hitting the water's surface if the sun was at its zenith, the disk would be visible at a depth corresponding to half of the total path: $85.96 \mathrm{~m} / 2=42.93 \mathrm{~m}$. Other than the methods he employed, the key notion was if the sun was at its zenith. That is, Secchi tried to define a normalized quantity, independent of observational conditions. His intuition was that when making a passive measurement of the interaction of sunlight with water, the environmental factors could be mathematically compensated in such a way that measurements become comparable and more directly related to seawater's inherent optical properties.

This insight on the impact of the sun's elevation, though pioneering, was limited by the narrow range of the water types he sampled. A further understanding of the phenomenon was available after other scientists collected additional data. Analysis of cruise data from expeditions by Josef Luksch (1836-1901) comprised the most complete optical studies in oceanography of the time, based on analyzing hundreds of Secchi disk and water color observations collected across nine years (18901898) in the Aegean, Levantine, and Red Seas. In Luksch's data analysis, a complete chapter was dedicated to the dependence of disk visibility on the sun's elevation (Luksch, 1901). It was summarized in the following comment: "The visibility depth in deep blue water increases with the increasing sun elevation. This increase is lower for the higher color numbers [greener waters]." ${ }^{35}$ Figure 7 shows box plots of all Luksch's data, arranged by sun elevation and color. From Luksch's data, two color clusters have been selected: blue waters (color 0 to 2.5) and green waters (color 4.5 to 8 ). Cloud cover has been limited to a maximum of 6 (in a scale from 0 to 10). This reanalysis confirms Luksch's conclusions: a steady dependence of Secchi disk depth on sun elevation is found, while such a pattern does not appear for green waters.

The Swiss limnologist FrançoisAlphonse Forel (1841-1912) also tried to observe the dependency of disk visibility on sun elevation, measuring at a fixed station in Lake Geneva on July 3, 1874, from $8 \mathrm{~h}$ to $19 \mathrm{~h}$ local time (Forel, 1895). He was disappointed at not being able to confirm Secchi's predictions: while the sun elevation ranged from $8.6^{\circ}$ to $66.26^{\circ}$, the Secchi disk depth did not go outside the interval 7.3-7.6 m during the whole day. ${ }^{36}$ However, he sampled the lake again in

\footnotetext{
32 Talché la profondità cresce coll'altezza del Sole.

33 Questa [influenza] è manifestissima.

34 Questo tragitto non è espresso per la semplice doppia profondità verticale del disco, ma deve determinarsi in ciascun caso dietro l'inclinazione del raggio incidente e rifratto, e l'altro riverberato dal piatto per arrivare all'occhio.

35 Die Sichttiefen in stark blauem Wasser nehmen mit dem wachsenden Sonnenstand zu. Diese Zunahme vermindert sich mit den höheren Farbennummern.

36 "[knowing] the argumentation and experiments of Father Secchi thus assigning a great influence to the height of the sun, I was very surprised by the results that I first obtained in Lake Geneva; for a long time I was unable to verify this influence of the height of the sun. On the same day, during the summer of 1874 , I found the limit of visibility so similar, whatever the time and therefore the height of the sun [...]. I couldn't even find a difference in this depth before or after sunset." Le raisonnement et l'expérience du P. Secchi attribuant ainsi une grande influence à la hauteur du soleil, j'ai été fort surpris des résultats que j'ai d'abord obtenus dans le lac Léman; pendant longtemps j'ai été incapable de constater cette influence de la hauteur du soleil. Je trouvais dans la même journée, pendant l'été de 1874, la profondeur limite de visibilité tellement semblable, quelle que fût l'heure et par conséquent la hauteur du soleil [...]. Je ne trouvais même pas de différence dans cette profondeur avant ou après le coucher du soleil.
} 
winter, on March 27, 1875, when there was higher water clarity. He measured $15 \mathrm{~m}$ with a sun elevation of 29 and $16.8 \mathrm{~m}$ for $46^{\circ}$, so the dependence on sun elevation seemed to be confirmed. In an interesting argument for a modern reader, Forel argued that his results were a result of water type. He made a distinction in which light extinction in Secchi's experiments was affected by "absorption," while in his case (high biological production in summer), light extinction was caused by "suspended material," which makes the light field become like "a fog." ${ }^{37}$

Current knowledge can explain why sun elevation plays a variable role in visibility, depending on water turbidity. Scattering by suspended particles increases the diffuse to direct ratio of the underwater light as turbidity increases, which results in a more isotropic light field. If the diffuse to direct ratio increases, the sun elevation loses impact in $\mathrm{K}_{\mathrm{d}}$ (the diffuse attenuation coefficient, that is, the rate at which the sum of sun and sky light attenuates with depth in the water) (Gege, 2012), which is the main optical variable that affects $\mathrm{z}_{\mathrm{SD}}$ (Lee et al., 2015). Unfortunately, these findings imply that it is not possible to build a $\mathrm{z}_{\mathrm{SD}}$ analytical model of separated variables (sun elevation and water quality). Developing a formula to correct Secchi disk readings for different sun elevations promises to be a challenging task. Analog theoretical work conducted to remove the angular dependence from satellite remote-sensing reflectance measurements also concluded that the correction varied with the water's optical properties (Lee et al., 2011).

Despite all this early evidence regarding how the sun's zenith affects disk visibility depending on the water's optical properties, published empirical relationships between uncorrected Secchi disk and other variables such as chlorophyll and total suspended matter are unfortunately very common today, and they should therefore be considered with caution. Correction of Secchi disk readings is mandatory not only for obtaining comparable data but also for comparison with satellite Secchi disk depth estimations, which refer to a standard zenithal sun position.

\section{THE DISSEMINATION OF THE SECCHI DISK}

Secchi's great skills in physics, his ability to stay current, and his scientific curiosity constituted an ideal background when he joined Captain Alessandro Cialdi on board the corvette Immacolata Concezione to conduct marine optical measurements. By reading Secchi's cruise report, written in a pedagogical style, we can appreciate a great intellect at work, demonstrating the worthiness of science as a model for rationality. Without the benefit of computers, complex instrumentation, and large

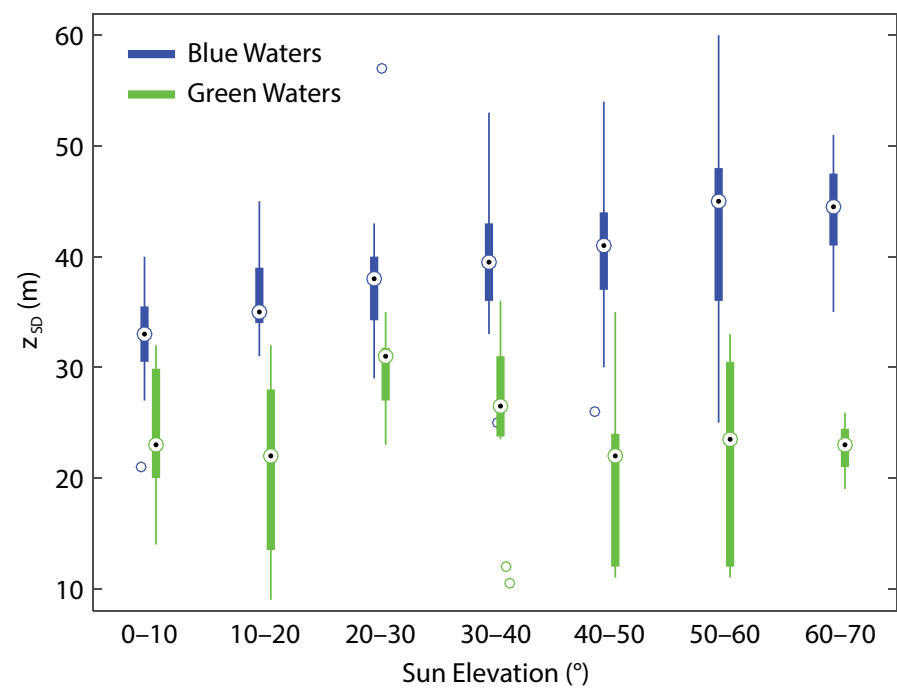

FIGURE 7. Secchi disk depth $\left(\mathrm{z}_{\mathrm{SD}}\right)$, arranged by sun elevation intervals for two water colors: blue ( $N=170$ data points) and green $(\mathrm{N}=75)$. Data digitized* from Luksch (1901). Box plots indicate the median (white circles with a black dot) and the interquartile range (thick bar). The whiskers (thin lines) extend to the most extreme data points that are not considered outliers (i.e., within 1.5 times the interquartile range away from the median). Outliers are individually plotted as colored circles.

${ }^{*}$ M.R. Wernand digitized Luksch's data before me, but after starting a quality check of his digitalization, I ended up redoing everything from scratch, which took me about a month of painstaking work. The result was a table of 752 stations containing color data, as well as ancillary meteorological, bathymetric, and sea surface data, of which around half contain Secchi disk depth and sun elevation as well. The table can be made available upon request to me.

data sets, Secchi did monumental work on the physics of the Secchi disk by designing the proper experiments, taking meticulous measurements, and interpreting the results based on knowledge of the time. The conclusions that Secchi extracted from his experiments are consistent with our current understanding of marine optics, 155 years later, and are still studied today. These include an accurate description of the methodology and an optical characterization of the method based on external factors that influence the transparency as well as the quality of the water. By following Secchi's deployment protocols and data analysis, the Secchi disk depth can become a quasi-inherent optical property of the water, with uncertainties that can be comparable to, or better than, those of other quantities measured with optoelectronic instrumentation.

For some years after Secchi's work, the name of the method seemed in dispute. Luksch (1901) stated: "To estimate the visibility depth, white disks were sunk into the sea." ${ }^{38}$ Luksch's use

\footnotetext{
37 "If the water contains suspended matter, the conditions are quite different. [...] the white disk [...], which we make it sink in such opaque water, we make it penetrate in a cloud, in a fog formed by the opaque corpuscles [...]. Under these conditions, the lighting, the brightness of the object that we contemplate, has almost no influence on its appearance or disappearance. As long as the dust, or the vesicles of the mist allow some light ray to pass between them, any body, even black, remains visible. Si l'eau contient des matières en suspension, les conditions sont tout autres. [...] le disque blanc que nous faisons descendre dans une eau ainsi opalinisée, nous le faisons pénétrer dans un nuage, dans un brouillard formé par les corpuscules opaques [...]. Dans ces conditions, l'éclairage, l'éclat de l'objet que nous contemplons, n'a presque aucune influence sur son apparition ou sa disparition. Tant que les poussières, ou les vésicules du brouillard laissent passer entr'elles quelque rayon lumineux, un corps quelconque, même noir, reste encore visible.
} 
of two disks with similar sizes to Secchi's (45 $\mathrm{cm}$ and $2 \mathrm{~m}$ ) suggested that he was aware of Secchi's work, ${ }^{39}$ but Secchi's name was not mentioned in his series of reports, suggesting an underlying political war. Fortunately for Secchi, his name was linked to the disk forever after the intervention of Forel. He wrote in the second volume of his treatise "Le Léman" (Forel, 1895), “To study the transparence $[. .$.$] of the water, the sailors of all$ times have made a white body sink into the water, a porcelain dish, and have written down the depth at which it disappears from sight. This elemental observation has been elevated to a scientific method by the Father A. Secchi, of Rome, which in 1865, made a campaign off Civitavecchia to determine, by means of this process, the transparence of the water of the Mediterranean Sea." ${ }^{40}$ With this direct recognition by Forel, ${ }^{41}$ Secchi won the battle for credit in the long term.

By the beginning of the twentieth century, the term "Secchi disk" was being used worldwide. The disk's diameter quickly evolved to the $20-30 \mathrm{~cm}$ used today following Forel's recommendations. The method spread among oceanographers and limnologists, though its use in oceanography has decreased in the last 40 years. In limnology, the Secchi disk technique has aged better and is still very popular. As an example, $\sim 450,000$ centralized measurements in global marine waters (NOAA, 2013) are doubled in number by centralized data from US lakes alone (Bigham Stephens et al., 2015). Therefore, it is reasonable to estimate that Secchi disk measurements in lakes worldwide may exceed by several times the number in seawater. Causes for this divergent fate may be the strong influence of Forel among limnologists, and the characteristics of their field, more prone to the use of simpler and lighter instrumentation than oceanography.

The science and the methodology of the Secchi disk, on the other hand, did not take off, and the Secchi disk was left as a semi-quantitative method, without any physical characterization, acquisition protocol, and data correction. Physical studies were performed many decades later (Duntley, 1952, reissued 1960; Preisendorfer, 1986), but they were largely ignored by the community of Secchi disk practitioners. Fortunately, recent contributions to the physics of the Secchi disk (Bowers et al., 2020; Jiang et al., 2019; Lee et al., 2015, 2018) are reaffirming the method, and publications are booming again, especially from the Chinese community ( $\mathrm{He}$ et al., 2017; Zhang et al., 2018; Zhou et al., 2019), and profiting from the retrieval algorithms for satellite data (Feng et al., 2019; Liu et al., 2020).

The Secchi disk depth is the optical property that allows the construction of the longest time series that can bridge the current status of the ocean and lakes to that more than a century ago. Connecting Secchi disk science to modern optical oceanography must advance on various fronts. A visibility theory of the Secchi disk that is derived from first electromagnetic principles will warrant the broadest range of applicability and will be much preferred to the simpler, and seriously limited, regression models. In addition, such theory will naturally account for dependence on the disk's properties, sea state, illumination, observation conditions, and optical properties of the water. With certain assumptions, a simplified formula will be derived from it in order to permit retrieval of optical properties from Secchi disk depth measurements. A starting point could be a recent horizontal atmospheric visibility theory (Lee and Shang, 2016), whose adaptation to the Secchi disk seems feasible. Achieving this task would also warrant comparability of in situ data to satellite estimations, the latter seen by many as the future of the Secchi disk. @

\section{ONLINE SUPPLEMENTARY MATERIALS}

A Microsoft Excel table of Secchi's georeferenced data set is available online at https://doi.org/10.5670/ oceanog.2020.301.

\section{REFERENCES}

Bigham Stephens, D.L., R.E. Carlson, C.A. Horsburgh, M.V. Hoyer, R.W. Bachmann, and D.E. Canfield. 2015. Regional distribution of Secchi disk transparency in waters of the United States. Lake and Reservoir Management 31(1):55-63, https://doi.org/ 10.1080/10402381.2014.1001539.

Bouguer, P. 1729. Essai d'optique sur la gradation de la lumière. Claude Jombert, Paris, $164 \mathrm{pp}$

Bowers, D.G., E.M. Roberts, A.M. Hoguane, K.A. Fall, G.M. Massey, and C.T. Friedrichs. 2020. Secchi disk measurements in turbid water. Journal of Geophysical Research 125(5):e2020JC016172, https://doi.org/10.1029/2020jc016172.

Chinnici, I. 2019. Decoding the Stars: A Biography of Angelo Secchi, Jesuit and Scientist. R.A. Maryks, ed., Brill, Leiden, The Netherlands.

Cialdi, A. 1866. Sul moto ondoso del mare e su le correnti di esso specialmente su quelle littorali. Tipografia delle belle arti.

Duntley, S.Q. 1952, reissued 1960. The Visibility of Submerged Objects (Chapters 1 through 4). Office of Naval Research, Visibility Laboratory, Massachusetts Institute of Technology.

Feng, L., X. Hou, and Y. Zheng. 2019. Monitoring and understanding the water transparency changes of fifty large lakes on the Yangtze Plain based on long-term MODIS observations. Remote Sensing of Environment 221:675-686, https://doi.org/10.1016/ j.rse.2018.12.007.

Forel, F.A. 1895. Le Léman: monographie limnologique. F. Rouge, ed., vol. 2. Librairie de l'Université, Lausanne, $651 \mathrm{pp}$.

Gege, P. 2012. Analytic model for the direct and diffuse components of downwelling spectral irradiance in water. Applied Optics 51(9):1,407-1,419, https://doi.org/10.1364/A0.51.001407.

Graham, J.J. 1966. Secchi disc observations and extinction coefficients in the central and eastern North Pacific Ocean. Limnology and Oceanography 11(2):184-190, https://doi.org/ 10.4319/lo.1966.11.2.0184.

Haltrin, V.I. 1998. Spectral relative clarity of Black and Aegean Seas. In Proceedings of the IGARSS '98. Sensing and Managing the Environment. 1998 IEEE International Geoscience and Remote Sensing Symposium Proceedings, July 6-10, 1998, vol. 2 , https://doi.org/10.1109/IGARSS.1998.699624.

\footnotetext{
39 Willi Ule's article in 1897 showed that, during those years, Secchi's work was known within the German-speaking community: "The visibility was estimated with the aid of Secchi's disk." (Ule, 1897) Die Durchsichtigkeit wurde mit Hilfe der Secchi'schen Scheibe bestimmt.

40 Pour étudier la transparence [...] des eaux, les navigateurs de tous les temps ont fait descendre dans l'eau un corps blanc, une assiette de porcelaine et ont noté la profondeur à laquelle elle disparaît à l'œil. Cette observation élémentaire a été élevée à la valeur d'une méthode scientifique par le Père A. Secchi, de Rome, qui, en 1865, fit au large de Civita-Vecchia une campagne pour déterminer, par ce procédé, la transparence des eaux de la Méditerranée.

41 Ule regretted: "Forel has attributed this method to the Italian Secchi and thanks to him the corresponding disk has been given the name Secchi's disk, although it had been used even before by Lorenz von Liburnau and myself." (Ule, 1899) Forel has dieses Verfahren nach dem Italiener Secchi bezeichnet und durch ihn hat die betreffende Scheibe den Namen Secchi'sche Scheibe erhalten, obwohl sie von Lorenz von Liburnau und dem Verfasser früher auch schon angewendet worden ist.
} 
He, X., D. Pan, Y. Bai, T. Wang, C.-T.A. Chen, Q. Zhu, Z. Hao, and F. Gong. 2017. Recent changes of global ocean transparency observed by SeaWiFS. Continental Shelf Research 143:159-166, https://doi.org/10.1016/j.csr.2016.09.011.

Jiang, D., B. Matsushita, F. Setiawan, and A. Vundo. 2019. An improved algorithm for estimating the Secchi disk depth from remote sensing data based on the new underwater visibility theory. ISPRS Journal of Photogrammetry and Remote Sensing 152:13-23, https://doi.org/10.1016/ j.isprsjprs.2019.04.002.

Lee, Z.P., K. Du, K.J. Voss, G. Zibordi, B. Lubac, R. Arnone, and A. Weidemann. 2011. An inherentoptical-property-centered approach to correct the angular effects in water-leaving radiance. Applied Optics 50(19):3,155-3,167, https://doi.org/10.1364/ A0.50.003155.

Lee, Z.P., S. Shang, C. Hu, K. Du, A. Weidemann, W. Hou, J. Lin, and G. Lin. 2015. Secchi disk depth: A new theory and mechanistic model for underwater visibility. Remote Sensing of Environment 169:139-149, https://doi.org/10.1016/ j.rse.2015.08.002.

Lee, Z.P., and S. Shang. 2016. Visibility: How applicable is the century-old Koschmieder model? Journal of the Atmospheric Sciences 73(11):4,573-4,581, https://doi.org/10.1175/jas-d-16-0102.1.

Lee, Z.P., S. Shang, K. Du, and J. Wei. 2018. Resolving the long-standing puzzles about the observed Secchi depth relationships. Limnology and Oceanography 63(6):2,321-2,336, https://doi.org/ 10.1002/Ino.10940.

Liu, Y., C. Xiao, J. Li, F. Zhang, and S. Wang. 2020. Secchi disk depth estimation from China's new generation of GF-5 hyperspectral observations using a semi-analytical scheme. Remote Sensing 12(11):1849, https://doi.org/10.3390/ rs12111849.

Luksch, J. 1901. Untersuchungen über die Transparenz und Farbe des Seewassers. (Mit 3 Tafeln und 11 Textfiguren.), Berichte der Commission für Erforschung des östlichen Mittelmeeres. (Erste Reihe.) Denkschriften der Akademie der Wissenschaften. Math. Natw. KI. Frueher: Denkschr. der Kaiserlichen Akad. der Wissenschaften. Fortgesetzt: Denkschr. oest. Akad. Wiss. Mathem. Naturw. Klasse.

NOAA. 2013. Secchi disk and water color observations, https://www.nodc.noaa.gov/OC5/WOD/ secchi-data-format.html.

Pitarch, J. 2017. Biases in ocean color over a Secchi disk. Optics Express 25(24):A1124-A1131, https://doi.org/10.1364/OE.25.0A1124.

Preisendorfer, R.W. 1986. Eyeball optics of natural waters: Secchi disk science. NOAA Technical Memorandum ERL PMEL-67.

Raman, C.V. 1922. On the molecular scattering of light in water and the colour of the sea. Proceedings of the Royal Society of London. Series A, Containing Papers of a Mathematical and Physical Character 101(708):64-80, https://doi.org/10.1098/ rspa.1922.0025.

Secchi, A. 1860. Catalogo di 1321 stelle doppie misurate col grande equatoriale di Merz all'Osservatorio del Collegio Romano, e confrontate colle misure anteriori. Tipografia delle belle arti, Roma, $120 \mathrm{pp}$.

Secchi, A. 1863. Sull'ecclisse solare totale osservato in Spagna nel 18 luglio 1860. Memorie dell'Osservatorio del Collegio Romano 2:33-52.

Secchi, A. 1865. Relazione delle esperienze fatte a bordo della pontificia pirocorvetta Imacolata Concezione per determinare la trasparenza del mare; Memoria del P.A. Secchi. I/ Nuovo Cimento Giornale de Fisica, Chimica e Storia Naturale 20:205-238.

Secchi, A. 1870. Descrizione del meteorografo dell'Osservatorio del Collegio Romano. Belle Arti, Roma, 96 pp.

Ule, W. 1897. Der Starnberger See. Geographische Zeitschrift 3(10):545-557.
Ule, W. 1899. Die Gewässerkunde in dem letzten Jahrzehnt. Geographische Zeitschrift 5(8):434-456.

Wernand, M.R. 2010. On the history of the Secchi disc. Journal of the European Optical Society Rapid Publications, vol. 5, https://doi.org/10.2971/ jeos.2010.10013s.

Wernand, M.R., and H.J. van der Woerd. 2010. Spectral analysis of the Forel-Ule Ocean colour comparator scale. Journal of the European Optical Society - Rapid Publications, vol 5, https://doi.org/ 10.2971/jeos.2010.10014s.

Wernand, M.R., and W.W.C. Gieskes. 2011. Ocean Optics from 1600, Hudson to 1930, Raman: Shifting Interpretation of Natural Water Coloring. Union des océanographes de France, Paris.

Zhang, Y., B. Qin, G. Zhu, K. Shi, and Y. Zhou. 2018. Profound changes in the physical environment of Lake Taihu from 25 years of long-term observations: Implications for algal bloom outbreaks and aquatic macrophyte loss. Water Resources Research 54(7):4,319-4,331, https://doi.org/10.1029/ 2017 wr022401.

Zhou, Q., W. Wang, L. Huang, Y. Zhang, J. Qin, K. Li, and L. Chen. 2019. Spatial and temporal variability in water transparency in Yunnan Plateau lakes, China. Aquatic Sciences 81(2):36, https://doi.org/ 10.1007/s00027-019-0632-5.

Воробьёв, Н.И. 1926. Материалы по лимнологии Волжско-Камского Края. Общество естествоиспытателей Казанского государственного университета. Казань, 72 рр.

\section{ACKNOWLEDGMENTS}

I thank Oceanography Editor Ellen Kappel and Associate Editor Grace Chang for their guidance and feedback. Reviews and support by Zhongping Lee and David Antoine were greatly appreciated. Comrade Falcini is thanked for feedback on an early manuscript draft. Translation of the memorial plaque in Figure B-1 from Latin was made by Leopoldo Gamberale of the Sapienza University at Rome. Oksana Viktorovna Knyazeva, of the North Caucasus Federal University at Stavropol, assisted with text in the Russian language. The Copernicus Climate Change Service (C3S_511) has been financially supportive.

\section{AUTHOR}

Jaime Pitarch (jaime.pitarchportero@artov.ismar. cnr.it) is a scientist at the Consiglio Nazionale delle Ricerche, Istituto di Scienze Marine, Rome, Italy.

\section{ARTICLE CITATION}

Pitarch, J. 2020. A review of Secchi's contribution to marine optics and the foundation of Secchi disk science. Oceanography 33(3):26-37, https://doi.org/10.5670/oceanog.2020.301.

\section{COPYRIGHT \& USAGE}

This is an open access article made available under the terms of the Creative Commons Attribution 4.0 International License (https://creativecommons.org/ licenses/by/4.0/), which permits use, sharing, adaptation, distribution, and reproduction in any medium or format as long as users cite the materials appropriately, provide a link to the Creative Commons license, and indicate the changes that were made to the original content. 